\title{
THE PLACE OF PHILOSOPHY IN INTERNATIONAL LAW
}

\section{Edward Dumbauld $†$}

In view of the increasing importance of law in international affairs ${ }^{1}$ and of philosophy in legal studies, ${ }^{2}$ it becomes of interest to examine the place of philosophy in international law. Unfortunately, this topic has been somewhat neglected by modern American jurists." The tendency to "conceive of law as a body of devices for the furtherance of business" 4 has led us to view international law solely as an instrumentality of commerce and diplomacy. ${ }^{5}$ Yet weighty voices among us sanction a recurrence to the

$\dagger$ A. B., I926, Princeton University; LL.B., I929, LL. M., I930, Harvard University; Dr. Jur., 1932, University of Leyden. Member of the Fayette County, Pennsylvania, Bar; author of Interim Measures of Protection in International Controversies (i932) and of articles in various legal periodicals.

x. For recent discussions see SIR JohN Fischer WIILIams, The Place of Law in International Affairs, in Chapters on Current International Law and the League of Nations (I929) c. II, 28-63; Dumbauld, Legal Limitations on War-making (I930) I8 GEo. L. J. 83; COUdert (I931) InTERnatronal Conciliation 926, 93I; Brierly, The Function of Law in International Relations, in Problems of PeACE (3d ser. I929) 278: LaUterpacht. The Function of LAW IN THE INTERNational COMMUNity (1933).

The spread of a violent form of nationalism ("integral" or "totalitarian" nationalism), extolling the state as the be-all and end-all of human existence and glorifying conquest abroad as well as tyranny at home, is without doubt inimical to the maintenance of peace and respect for law and order in the international community. C. D. Burns, Nationalism and Internationalism, in Problems of Peace (2d ser. I928) 336; Hayes, The Historical EvoLUTION of MOdERN NATionalism (I93I) I66; F. L. Schumann, The Political Theory of German Fascism (I934) 28 AM. PoL. SCI. Rev. 2IO. But this does not eliminate the role of international law in regulating the multiplicity of international contacts inescapable under modern conditions. However fanatically one nation or another may arrogate to itself a mission to subdue and govern the entire earth in accordance with its particular brand of imperialistic or communistic dogma, its dealings with other unconquered nations must remain subject to international law until that universal dominion is in fact attained, an unlikely consummation in view of the large number of competing nationalisms of equal vigor. Unenlightened national policies may of course affect the content of substantive international law and produce a situation requiring reform.

2. Dean Pound and Professors Llewellyn, Morris R. Cohen, and John Dickinson, are outstanding figures in the group of present-day thinkers who give weight to philosophical considerations in their legal writings. For a recent statement see K. N. Llewellyn, On Philosophy in American Law (1934) 82 U. of PA. L. Rev. 205. As an excellent example of the application of philosophical knowledge to legal problems see FEIIX S. CoEEN, ETHICAL SySTEMS AND LEGAL IDEALS (1933).

3. Thus Professor Whitton rightly speaks of ".

the philosophy of international law, that branch of the droit des gens, which alas, has few amateurs in the United States". Book Review (193I) 25 AMr. J. InT. L. 409, 410. Dean Pound's paper, Philosophical Theory' and International Lawe (I923) I Biblotereca Visseriana 72, stands alone as a locus classicus in our literature. Mention might also be made in this connection of Borchard, Political Theory and Intemational Law, in Merriam and BarNes, History of Polttical THeortes (I924) c. IV, I20.

4. This standpoint is criticised by Pound, The Call for a Realist Jurispmedence (I93I) 44 HARv. L. REv. 697, 708-9. Compare the complaint of a German scholar, ZITELAMAN , DIE UNVOLKKOMMENHEIT DES VöLKERRECHTS (19I9) I4; "Wir haben das Völkerrecht geschichtlich und politisch, auch allgemein philosophisch, aber nicht genug juristisch behandelt".

5. John Hanna, The Aims and Methods of Legal Education (1931) 7 AMr. L. Sckoor. Rev. I4I, 144, Cf. Sir John Fischer Williams, The Legal Character of the Bank for International Settlements (r930) 24 AMr. J. INT. LAw 667; "The work of the experts was, all through, characterized by a profound and possibly not unjustified mistrust of governments. In their view, governments had failed to solve the reparation problem; the solution was to be sought in the action of business men, superior to the passions of the crowd and independent of rulers who are dependent on the crowd". 
juristic tradition of ampler vision which animated an age whose achievements challenge comparison with our own. ${ }^{6}$ During the formative period of American law, philosophical elements were not neglected. Not only our own jurisprudence, but the law of nations as well, was enriched by the wisdom and learning of Marshall, Jefferson, Wilson, Kent and Story. ${ }^{7}$ It would therefore seem proper to return to the point where the paths of jurisprudence and philosophy diverge and from there carry on the philosophical method. ${ }^{\mathrm{s}}$

What is desired, however, is not a return to the specific "natural law" doctrines which prevailed in the past and gave to jurists of that day the philosophical basis for the legal structure which they reared. American constitutional law affords impressive warnings against such a course. But reliance upon philosophical method does not necessarily mean reliance upon the outmoded tenets of any particular philosophical system. "When one calls for philosophy of law he should demand nothing less than application to the problems of the legal order of the best and most fruitful ideas and methods that the philosophical armory of today affords." 9 The duty of seeking an adequate philosophical foundation is all the greater because of the fact that even historical and analytical jurists, who profess to repudiate philosophy, can not in reality escape the inexorable necessity of relying upon certain philosophical postulates, although they do so blindly and without reflection. ${ }^{10}$

6. "One of the valuable results still to be obtained from reading these classic treatises which helped to form so many great lawyers is the feeling that one brings away that property law and commercial law are not the whole of the law, but are only parts of a system which embraces within its scope all the fundamental problems of human and social relations, of a human organization of society. In so far as we close the shutter to the prospective lawyer on all but the technical commercial aspects of law, we not merely degrade law from a profession into a mere means of livelihood, but we also impair the vocational fitness of coming generations of lawyers to deal with the largest and most important problems which under our system of government devolve upon the bar." John Dickinson, Legal Education and the Law School Curriculum (193I) 79 U. OF PA. L. Rev. 424, 435.

7. T. W. Balch, The United States and the Expansion of the Law Between States (1915) 64 U. of PA. L. REv. II3; J. B. Moore, John Marshall (IgOI) I6 PoL. Scr. Q. 393; L. M. Sears, Jefferson and the Law of Nations (I9I9) I3 AM. PoL. Scr. Rev. 379; R. C. Adams, The Legal Theories of James Wilson (1920) $68 \mathrm{U}$. of PA. L. REv. 337; M. O. Hudson, The Teaching of International Law in America (I929) I5 A. B. A. J. I9; C. M. Wiltse, Thomas Jefferson on the Laze of Nations (1935) 29 AM. J. INT. LAW 66.

8. Pound, supra note 3 , at 75. Professor Hudson considers renovation of the philosophical bases of international law as one of the two major tasks confronting jurists of our century. The Prospect for International Law in the Twentieth Century (Ig25) Io CoRN. L. Q. 419, 423. The need for a new philosophy of international law is likewise voiced by Laski, The Theory of an International Society, in Problems of PEACE (6th ser. 1932) 188.

9. Pound, supra note 3 , at 75.

Io. Id. at 86; Verdross, DIE VERFassuNG DER VöLKERRECHTSGEMEINSCHAFT (I926) \$ 7. ". . . on ne peut pas faire du droit sans un minimum de philosophie. . . " Le fur (France, Ig27-III) I8 RECuEIl DES CouRs (Académie de Droit International de la Haye) 263. "No juristic effort is possible except as it is based on some philosophy, and the very men who are most loath to admit this fact are they who most blandly and blithely indulge their philosophical assumptions. International law has suffered from nothing else as from our unwillingness to deal with its underlying philosophy in the open." Hudson, supra note 8, at 423, 424 . 
Since philosophy of law, therefore, is the application of philosophy to problems of the legal order, and since international law is the application of law to problems of international relations, ${ }^{11}$ we may expect to find that every system of philosophy which has left its impress on jurisprudence as a whole will have corresponding implications for international law. ${ }^{12}$ In view of this parallelism, a scheme of treatment which is familiar to American readers from its use by Dean Pound in his classification of schools of juristic thought ${ }^{13}$ should not be out of place here. We shall therefore proceed to consider the opinions of authorities on international law with respect to: (I) the binding force of law; (2) the nature of law; (3) the end of law. ${ }^{14}$

\section{From What Does International Law Derive Its Binding Force?}

Our inquiry is limited to the problem of what makes international law legally binding. That a moral obligation to obey law also exists, within limits, one feels instinctively. ${ }^{15}$ But the nature and extent of that obligation is necessarily determined by a rule of morals. Law, as the work of man, can claim no absolute validity; ${ }^{16}$ it is a moral imperative only when it is so recognized by conscience. ${ }^{17}$ The norms ${ }^{18}$ of law and those of morals constitute independent realms. ${ }^{19}$

II. Verdross, op. cit. supra note Io, at $6 \mathrm{x}$; NIEMEYER, VölKERRECHT (Ig23)' Io. $C f$. Feirchenfeid, Public Debis and State Succession (I93I) 582.

12. Kunz, VölKERRECHTSWISSENSCHAFT UND REINE RECHTSLEHRE (1923) 66, comments on the tendency to apply every philosophical system to law, ". . . es für die Jurisprudenz zu verwerten". The same author in (I929) 9 ZEITSCHRIFT Für ÖFFENTLICHES RECHT 473, points out that Professor Korovin's book there reviewed is an application to international law of the philosophy of Marx. Terders, StAat EN Volkenrecht (I927) makes similar use of the philosophy of Hegel.

I3. See Llewellyn, Some Realism About Realism-Responding to Dean Pound (I93I) 44 HaRv. I. REv. I222, for an appreciation of the extent to which Dean Pound's classifications have been influential in acquainting America with the doctrine of foreign and native jurists.

I4. The same classification is followed by RADBRUCH, GRUNDzÜGE DER RECHTSPHILOSOPHIE (IgI4).

I5. WILIIAMS, op. cit. supra note $\mathrm{I}$, at I5.

16. FEII.CHENFEID, op. cit. supra note II, at 601 .

I7. Until then it is merely external constraint, which may compel obedience but cannot beget the obligation to obey. LAUN, RECHT UND SITTIICEkEIT (2d ed. I927) 15, 16; RADRRUCH, op. cit. supra note I4, at 54 ; RousSEAU, CONTRAT SocIAL, I, iii.

18. By norms is meant propositions which do not purport to state facts but to set up standards to which conduct ought to conform. The differentia specifica between law and other norms presents a controversial problem of jurisprudence not peculiar to international law. See Pound, Law and Morals (2d ed. I926); Somló, Juristische Grundlemre (I9I7) ; J. Van Kan, INLetding tor de Rechtswetenschap (4th ed. I93I) II ; MausbacH, NATURRECET UND VöLKERRECHT (I9I8) 48, 58, 90; RADBRUCH, op. cit. supra note I4, at 39 ; Verdross, op. cit. supra note Io, at 3, 4; Det Vecchio, LA Grustizia (2d ed. I924) 46; Dex Vecchio, Lezioni di Filosofia deL DIRITTo (I93I) I8I; TRIEPEL, VölkERREChT UND LANDESRECHT (1899) 107-9; SCHOLTEN, BeschouWINGEN OVER RECHT (I924) 35, 203; WILLIAMs, op. cit. supra note I, c. I; and the authorities cited in Dumbautd, InTERIM MEasures of Protection in International Controversies (I932) 8. One might thus summarize the thought: Law is a norm commanding a certain course of conduct because it is considered as being just; justice is a virtue unlike courage, temperance, chastity, piety, etc., in that it regards others and confers rights upon them; therefore external constraint is proper, and is called for by legal norms.

Ig. Verdross, Zur Konstruktion des Völkerrechts (Deutschland, I9I4) 8 ZEITsCHRIFT FÜR VÖLKERRECHT 332. 
It is clear, moreover, that legal obligation can flow only from a rule of law. A given norm can be regarded as legally binding only when a higher rule of law, of superior authority, has stamped it as such. Thus a city ordinance has the force of law because a state statute has given it that effect; the acts of the state legislature in turn are law only because the state's constitution has vested the legislature with law-making power. Every rule of law is thus part of a legal system; ${ }^{20}$ and every legal. system rests ultimately upon its "constitution", a fundamental norm from which all other legal rules derive their validity. ${ }^{21}$ What is the constitution which gives binding force to the legal system known as international law?

Since it is the constitution of positive international law which we seek, we must inquire what legal rules are presupposed by observed practice. ${ }^{22}$ To be scientific, one must systematize all the positive rules of international law, rather than deny the legal value of everything inconsistent with a preconceived theory. ${ }^{23}$

Due weight should then be given to the following points. (I) The existence, indeed the importance, of what is known as international law is not denied by those who, because adhering to a definition of law which is nothing but a description of municipal law (exclusive of certain parts of constitutional law), ${ }^{24}$ insist that international law is not law. ${ }^{2 \bar{J}}$ (2) The

20. Bruns, Völkerrecht als Rechtsordnung (Deutschland, I929) I ZEITsCHRIFT F. AUS. öfF. RT. U. VốlKERRECHT, Teil I, 10; Perassi, Teoria dommatica delle Fonte di Norme giuridiche in Diritto internazionale (Italia, I9I7) II Rrv. Dr DIR. INT. 216.

21. AnzilotTI, Corso ( $3 \mathrm{~d}$ ed. I928) I, 43. In addition to its constitution a legal system presupposes a community (Rechtsgemeinschaft). Bruns, op. cit. supra note 20, at to. There are also as a rule organs for legislation and enforcement of law. That the legislative functron need not, and cannot to advantage, be exercised by the wielder of physical power is declared by FeILCHENFELd, VölkERRECHTSPOLITIK als WissenschaFT (I922) I72. The same author in PUBlic DebTs and STAte SuCCEssion (I93I) 60I, observes: "Most writers on international law fail to distinguish between 'constitutional' and other rules". Among those recognizing the distinction may be named Verdross, Anzilotti, Cavaglieri, Strupp, Balladore-Pallieri, Perassi, Bruns, Kelsen and perhaps Triepel, Politis and Sir John Fischer Williams. Feilchenfeld's statement that his use of the term "constitution of international law" differs somewhat from Verdross's "Verfassung der Völkerrechtsgemeinschaft", in that it "does not imply that the persons in international law form an organized community", rests upon a misconception of Verdross's meaning. By "community" Verdross means the conduct in the external world which the law regulates, "den Inbegriff der durch die Rechtsordnung geregelten Handlungen". VERDRoss, op. cit. supra note 10 , at 6 . The legal persons recognized by international law are a community only by reason of their being subject to that law, and are organized only to the extent to which it prescribes.

22. VERDRoss, $o p$. cit. supra note Io, at $6 ; \cdot$ VERDRoss, DIE ETNHEIT DES RECHTLICHEN WetrbildEs (I923) 82, I18; Verdross, Grundlagen und Grundlegungen des Völkerrechts (Deutschland, I92I) 29 Niemeyers Zeitschrift Für INTERNationales Recht 65, 74.

23. Id. at $8 \mathrm{I}$. Kelsen, Allgemeine StaAtslempe (I925) contends that the observer is free to choose his own hypothetical constitution and to treat as law, and hence material for legal science, only that part of what claims to be law which conforms to the constitution so chosen. Thus, he says, it is impossible to refute the standpoint of an anarchist who insists that law in the capitalist state is nothing but force. Verdross, op. cit. supra note IS, at I9, replies that the anarchist as a scientific observer of facts can not deny that the force in question professes to be a norm. Kunz is very insistent that not every hypothesis is a scientific one. (Belgique, 1925) 52 R. D. I. L. C. 588. $292-4$

24. Joh nassett Moore, International Law and Sone Current Illusions (ig24)

25. Hold-Ferneck, Lehrbuch des Völkerrechts (1930) I, 78; Philip Marshall Brown, International Realtites (1917) t04. 
technique of international law is a legal technique. ${ }^{26}$ (3) The content of international law, in view of its reception as part of the law of the land, is important for the lawyer in his practice. (4) The relation of international law to topics admittedly legal is so close, that to be properly understood they must be studied together.

It is quite correct, therefore, to insist upon the teaching of international law in law schools as a legal, rather than political, science. ${ }^{2 t}$ it possible, without disregarding facts or unduly widening our definition of law, our legal system as constructed by philosophical theory should harmonize with practical requirements by including international law."s We now proceed to examine various constructions which have been advanced.

\section{A. Systems Based on Supernational Natural Law.}

Of venerable antiquity, coeval with our international law itself, is the view which bases its binding force upon natural law. This doctrine treats international law and internal law as identical in character, but in resting both upon a basis of ethical and political speculation does not appeal to the modern jurist. ${ }^{29}$ The Spanish jurist-theologians made international law

26. The contrast between canon law on the one hand and Christian ethics or the considerations affecting the selection of an ecclesiastical functionary on the other illustrates the distinctiveness of a legal technique. C f. John DICKINSON, A WORKIng TheORY of SoverEIGNTY (I92S) 24.

27. Hudson, supra note 7 , at 23; Potter, Introduction to the Study of Internatronal GovERNMENT ( $3 \mathrm{~d}$ ed. 1928) ix. It is of course true that a certain knowledge of international law is required by intelligent laymen for the proper performance of their civic duties. But the same is true of constitutional and commercial law, and the knowledge in question is quite different from that needed by a practicing lawyer. See EAGLETON, INTERNATIONAL GoverNMENT (1932) v.

The separate and distinct sciences which take as their respective provinces law, politics, ethics, economics, history, etc., do not lose their identity and essential distinguishing characteristics by reason of the mere fact that the social phenomena subjected to their scrutiny happen to be phenomena of international life. (It is possible to group the pertinent subdivisions of the several different sciences which touch upon international life into a composite science of international affairs as a whole, designated in German by the term Internationallelure. See H. Kraus, Gedanken über StaAtsethos in INTERnationalen VerkenR (ig25) 7r.) It is therefore undesirable to adopt a conception of law which results in classifying international law as morality or politics.

28. So Schoen. Zur Lehre von den Grundlagen des Völkerrechts (Deutschland, 1915) 8 ARChiv F. ReChtS- U. WIRTSCh AFTSPhilosophie 292, urges that the same foundation for the validity of international law as for other law should be established. For there can be only one definition of law for the jurist. International law, if it is law at all, has the same essential characteristics (wesensgleich) as private law or criminal law (as to which see WexzEI, JuRistische Gru dPPRobleme (1920) 357,358,397,398). But it is important to observe that it is not necessary that international law resemble other branches of law in all respects, but only in those which are essential to the idea of law. ANzirotri, Corso dr Diritro InterNAZIONALE (I912) I, 32. As will be seen later, Schoen in trying to bring international law within a too narrow definition of "law" has overlooked features which differentiate it from internal law and has thereby subjected himself to the criticism of Hold-Ferneck, op. cit. supra note 25, at 80, 86, 105, I12. Cf. also TrIEPEL, op. cit. supra note 18, at 9; DiCKIXson, ap. cit. suipra note 26 , at 23 .

29. BERGBOHM, JURISPRUDENZ UND RECHTSPhILOSOPHIE (I892) 526: "Recht is nur das positive Recht, und positives Recht nur was in einem geschichtlichen Vorgänge zu Recht gcworden ist, und die geschichtlichen Vorgänge . . . das sind die Rechtsbildungsformen oder sog. formellen Quellen des Rechts". On positivism see $\mathrm{K} \times \mathrm{N} 2$, op. cit. supra note 12, at 5 ; Verdross, Grundlagen (stipra note 22), at 81 ; STRUPP, GRundzüGe des POSITIVEN VöLKERRECHTS (4th ed. I928) 13. 
possible by deducing from reason or divine will rules binding the sovereign in his relations with other sovereigns, as well as those applicable to his relations with his own subjects and to their relations with each other. ${ }^{30}$ This fashion of treating together international law, constitutional law and political theory was carried over into the works of Protestant juristtheologians and subsequent writers. "The law-of-nature theory held on longer in international law than elsewhere. International lawyers had a sound instinct that creative thought was needed in a field of law where maturity was still far in the future; they had a subconscious feeling that any creative theory was better than the merely organizing and logically critical theories of nineteenth-century legal science. Yet the jurists of the last century were right in their judgment that the classical law-of-nature philosophy could serve them no longer . . . English and Americans were right in demanding a better theory of international obligation. But they were wrong in believing that they could find it without the aid of philosophy. On the whole the Continental speculative writers were nearer the truth. Their error was in relying upon a philosophical system, the philosophy of the seventeenth and eighteenth centuries, rather than upon philosophy." 31

This type of natural law with a definite content, as recently revived by Catholic writers, ${ }^{32}$ makes eternal rules of right and wrong the basis for state conduct. ${ }^{33}$ At the same time a type of formal natural law with a changing content has developed, postulating that law must be just, must correspond to the nature of things. ${ }^{34}$ Justice is eternal and immutable, but that which is just varies from time to time and from place to place. ${ }^{35}$ An intermediate view recognizes two specific rules: a state (I) must do no wrong to another (without compensation), and (2) must keep its promises. $^{36}$

30. Pound, The End of Law as Developed in Juristic Thought (IgI4) 27 HARv. L. Rev. $605,615,616$.

3I. Pound, supra note 3 , at 83,84 .

32. Cathrein, Die Gru ndiagen des Vól.kerrechts (IgI8); Mausbach, Naturrecht UND VÖLKERRECHT (I9I8).

33. "Nun gibt es viele Handlungen, die ihrer Natur nach ein geordnetes, gedeihliches Zusammenleben unmöglich machen. Dazu gehört Mord, Diebstahl, Ehebruch, falsche Zeugnis, Vaterlandsverrat $u$. dgl. Wenn in einer Gesellschaft diese Handlungen allgemein als gut und lobenswert angesehen würden, müsste sie in kürzester Zeit zugrunde gehen. . . . Jeder will sich selbst in dem was er seitz nennen kann; in seinem Leben, seiner Freiheit, seiner Frau, seinem Eigentum usw., erhalten wissen und darin nicht ungerecht geschädigt werden". CATHREIN, op. cit. supra note 32 , at 20,48 . So in international relations the rights of individuals must be respected regardless of their espousal by recognized states. Id. at 6I. "Die Staatsverträge verpflichten ähnlich wie die Privat verträge, weil es eine Forderung der natürlichen Gerechtigkeit ist, dass man rechtmässig eingegangene Verträge halte. Der Grundsatz: Du sollst die Verträge halten (pacta sunt servanda) ist eine notwendige und naheliegende Schlussfolgerung aus den beiden uns von selbst einleuchtenden Grundsätze, Man soll jedem das Seme geben und keinem ein Unrecht zufügen." Id. at 70.

34. NELSON, DIE RECHTSWISSENSCHAFT OHNE RECHT (I9I7) 2r5; von Bar, Grundlage u. Kodifikation des Völkerrechts (Deutschland, I9I2) 6 ARCHIV F. RECHTS- U. WIRTsCharTSPHILOSOPHIE 153; KOHLER, LEHRBUCH DER RECHTSPHILOSOPHIE (2d ed. I9I7) 52.

35. Aristotze, Nicomachean Ethics V, io; Verdross, Le Fondement du Droit International (France, I927-I) I6 RecueIl DEs CouRs (Académie de Droit International) 25I, 284 .

36. Le Fur, La Théorie du Droit Naturel (France, 1927-III) I8 RecueIL DES Cours 26r, at 389 . A supplementary principle is that of respect for authority. Id. at 390 . 


\section{B. Systems Based on the Authority of a Single State}

Writers belonging to the law of nature school conceived of law as a norm emanating from an authority superior to its subjects; and they regarded it as self-evident that such norms existed for both individuals and states. When jurists began to call for a positive, man-made, historical law, they did not discard the natural-law conception of law as the norm of a superior authority, but found in the rules imposed by a state upon its subjects a law which met both tests. It was not difficult to take the next step and assert that nothing could be positive law which was not the product of state will. ${ }^{37}$

From that standpoint, the rules commonly called international law, which do not even profess to be the creation of any single sovereign, are plainly not law. International law, where the subjects are states, is obviously a logical impossibility when it is required of law that it must come from the state as well as come from a source superior to its subjects. ${ }^{38}$

More moderate is the view of Hold-Ferneck, who concedes that a state may be bound by rules to which it has consented and which are consistent with its self-preservation. ${ }^{39} \mathrm{He}$ admits the existence and importance of international law, but denies its legal character by reason of its failure to provide order, security and peace, the three elements entering into his definition of law. ${ }^{40}$

Similar in substance is the theory of Eric Kaufmann, who declares that victorious war is the social ideal, and that the limits of international obligation are set by the self-interest of the state. He is able to conclude in favor of the legal nature of international law, however, by reason of his view that law need not necessarily imply subordination to a higher authority, but may be a law of co-ordination between equals. ${ }^{41}$

37. Cf. Wenzes, op. cit. supra note 28 , at 425 . Unless the state is defined as being the law-producing agency, one must say that positive law is that which is produced by the sources of law, rather than that which is produced by the state; otherwise it is a natural-law assumption on the "constitutional" plane. For a legal system could have other sources than the state (which has been the case historically) if by "state" is meant a sociological conception such as the highly developed administrative machines of our time. SomLo, op. cit. supra note 18, at 253, 270; Verdross, supra note 19, at 357; Perassi, supra note 20, at 223; Balladore-Pallieri, La forza obbligatoria della consuetudine internazionale (Italia, I928) 20 Rrv. DI DIR. INr. 338, 367, 372, 373; Del Vecchio, Sulla statualità del diritto (Italia, 1929) 9 Riv. INT. DI Filos IELL DIR.

38. Lasson, Princip und Zukunfr des Völkerrechts (I87I) 22. Chief among the "Völkerrechtsleugner", Lasson considers legal relations impossible among sovereign states, whose inevitable condition is that of hostility. The same thought recurs emphatically in Hold-FERNECK, op. cit. supra note 25, at II. Cf. BURCKHARDT, DIE UnVoll kOMMEN HeIT DES Völkerrechts (1923) 3. For criticism of Lasson, see BergboH M, StaAtsverträge Und GeSETZE ALS QUELIEN DES VöLKERRECHTS (I876); and WALZ, WESEN DES VÖLKERRECHTS UND KRITIK DER VÖLKERRECHTSLEUGNER (I930).

39. HOLD-FERNECR, op. cit. supra note 25, at 123, I86.

40. Id. at 78; AnerkenNung und Selbstbildung 66; Der StaAt als Ubermensch (Ig26) 8, 58. See also Bruns, supra note 20, at 9; RADBRUCH, op. cit. supra note I4, at 178. 41. KaUfmanN, Das Wesen des VölkerRechts und die Clausula rebus sic stanTIBUS (I9II) I53, I66, I99, 204. 
Another group of jurists sought to establish the legal nature of international law by putting it upon the same basis as internal law. This necessitated sacrificing the traditional conception of law, as well as the peculiar characteristics of international law. International law, thus degraded, becomes "äusseres Staatsrecht", that part of internal law which deals witl foreign affairs. ${ }^{42}$

Jellinek, an outstanding adherent of the "auto-limitation theory", seeks to avoid this criticism by the argument that the objective nature of the facts governed by international law logically necessitates the acceptance of identical rules by all states, so that the international law which each state binds itself to observe is not the result of mere chance or accident. ${ }^{43}$ Schoen $4:$ likewise insists that international law is not mere "äusseres Staatsrecht" but is law of a higher order, by reason of the fact that it is mutually binding and based on the common consent of states; for each state exacts acceptance by others as the condition of its own assent. Most ingenious in this respect is a theory formerly advanced by Verdross ${ }^{4 \overline{5}}$ to show why a state cannot by its own act liberate itself from the obligation of treaties, and how the whole system of international law is based on the state constitution in the same way as internal legislation. ${ }^{46}$ He points out that every state constitution. provides that the head of the state may negotiate treaties. Since these provisions may be interpreted as contemplating the conclusion of treaties, but not their breach, the state remains bound as long as its constitution is in force; ${ }^{47}$ for, just as the constitution may require the assent of both houses of Parliament to repeal statutes, so it may require the assent of both co-contractants to repeal the obligation of a treaty.

Verdross admits that Merkl's criticism of this theory as not adequately accounting for customary law is justified. For even if treaties need not be in writing, the actual constitutional provisions in force do have reference

42. A. ZoRN, GRUNdzÜGE des VöLKERRECHTS (2d ed. I903) 7 : "Völkerrecht ist juristisch Kecht nur, wenn und soweit es Staatsrecht ist". WENZEI, op. cit. supra note 28, at 403: "Das Völkerrecht gilt aus dem Staat, für den Staat und gegen den Staat. Es gilt mit derselben Autorität, wie das übrige aus dem Staat geltende Recht. Kürzer gesagt: Völkerrecht is staatliches Recht". Jellinek, Allgenreine StaAtslegre (3d ed. 1920) 479: "Dies ist der einzig mögliche Weg, das Völkerrecht rechtlich zu begründen. . . Alle Versuche, die Geltung des Völkerrechts auf eine über den Staaten stehende Rechtsquelle zurückzuführen sind misslungen und werden misslingen". C $f$. Schoen, supra note 28 .

43. Die rechtliche Natur DeR Staatenverträge (I880) 47,49 . If there were not an identical law, the validity of treaties, as a legally binding "consensus" ad idem", could not be made out.

44. Supra note 28, at 305, 306. Accord: WENZEL, op. cit. supra note 28, at 409 .

45. Supra note 19 . at 338,342 .

46. Id. at 339-353.

47. Id. at $340,347,355,357$. But the constitution is subject to amendment. WENzEL, op. cit. supra note 28 , at $505-509$, is logical in holding that a state may modify its own international law, but may violate that of another state, which will protest. Schoen apparently believes that since common consent is necessary for the existence of international law, it ceases with the cessation of such common consent. Op. cit. supra note $2 \mathrm{~S}$, at $3 \mathrm{IO}$. By the collective will theory a rule once established remains law until changed in the same manner. The "constitutional" theory also requires change in a duly authorized way. Perassi, supra note 20, at 294. 
to such written instruments, and not to "tacit pacts" establishing international rustom. One might rely upon the fact that many treaties incorporate by reference international law as a whole, including custom, but it is doubtful whether such an explanation would account for all existing international law. ${ }^{48}$

Moreover, it must be admitted that any theory, however ingenious, which bases international law upon the authority of a single state is open to certain fundamental objections.

(I) A state bound only by its own will is really not bound at all. It may change its will at any time. ${ }^{49}$ Even if the state constitution surrounds its international legislation with extraordinary formalities and guarantees, the state remains free, legally speaking, to nullify its international obligations at any time by taking the trouble to amend its constitution. But nothing is clearer as a matter of positive international law than that a state's international obligations are independent of domestic legislation, including constitutional provisions. ${ }^{50}$

(2) Consequently under this theory there could logically be no international responsibility for violations of international law, ${ }^{51}$ at least if a state took the precaution to declare that it no longer considered a rule as binding before violating it. ${ }^{52}$

(3) Nor could there ever be a controversy as to the existence or nonexistence of a particular rule of international law. By the very fact that it was disputed the rule would cease to exist. ${ }^{53}$

(4) Even if a state could bind itself and thus confer rights upon other independent states, ${ }^{54}$ it could not impose obligations upon them. ${ }^{55}$

(5) There could only be one state sovereign; ${ }^{56}$ but the right of all states to independent co-existence is one of the fundamental presuppositions of international law. ${ }^{57}$

48. Verdross, Grundlagen (supra note 22), at 70.

49. Even if earlier declarations of will prevailed over subsequent ones, the two wills would be distinct, like Philip drunk and Philip sober, and there would be no true "Selbstbindung". RADBRUCH, RECHTSPHILOSOPHIE (3d ed. I932) I8I.

50. Verdross, supra note 35, at 269; HoLD-FERNECK, supra note 25, at II5; ANzilotTr, Corso ( 3 d ed. 1928) I, 422.

5I. Strupp, Das völkerrechtliche Delikt (I920) 4.

52. MAusBaCH, op. cit. supra note 32, at I22, refers to the unfortunate effects of the German Chancellor's admission that the invasion of Belgium was a violation of law.

53. Perassi, supra note 20 , at 218 .

54. Such a possibility seems no more difficult than the creation of rights in internal law for the benefit of other persons than the state itself. Schoen, supra note 28, at 304; JELLINEx, ReChtLICHE NATUR (I880) 47.

55. Anzilotir, Tforia generale detla responsibmitì detlo stato (igoz) 3I; MaUsBACR, op. cit. supra note 32, at 100; Schoen, supra note 28 , at 307.

56. Kelsen, op. cit. supra note 23, at I23; RadBRUCH, RechtsphilosophIe (3d ed. 1932) I95; Burns, The Morality of Nations (igi6) 48.

57. LASSON, op. cit. supra note 38 , at 12; LiszT, VölKERRECHT (roth ed. 19r5) 65; Dumbauld, Toward a Self-Governing World (1929) 40 INT. J. ETHICs 92; I FAuchinIE, Traité de Droit international pUblic (I922) première partie, io, II; Trieper, $o p$. cit. supra note 18 , at 20 . 
(6) In truth it is impossible to meet the objection that the theory makes international law an "äusseres Staatsrecht"; it would involve a multiplicity of systems of international law. ${ }^{58}$ But the unity and universality of international law is one of its distinguishing features. ${ }^{50}$

(7) At least one rule of law is presupposed, that which gives binding force to the declared will of the state and determines what acts of human beings are to be regarded as declarative of that will. ${ }^{60}$

(8) No international obligation could survive a revolutionary change in the state constitution; yet state succession and its attendant obligations form an important chapter of international law. ${ }^{61}$

It thus appears that theories based upon the authority of a single state, however palatable they may be to nationalistic sentiment, ${ }^{62}$ are scientifically inadequate, as not explaining all the observed phenomena of positive international law.

\section{Systems Based on Supernational Authority}

Like the theories which have just been considered, those which seek a basis for international law which is superior to the authority of a single state may be divided into three groups, according to whether they take as such a basis might, state will, or a fundamental legal norm. The first alternative is represented by Somló, who finds in international law, as in internal law, a relation of subordination to the norms of a superior might. ${ }^{63}$ But since it does not correspond to his definition of law, ${ }^{64}$ Somlo erects international law as a separate and independent system of norms ${ }^{65} \mathrm{co}-$ ordinate with legal, conventional and moral norms. ${ }^{66}$

The second alternative is followed by what is perhaps the prevailing orthodox doctrine, which insists that the will of one state is insufficient as a basis for international law; and looks instead to the collective will of states. ${ }^{67}$ Hence, having different sources, as well as different provinces,

58. WENZEL, op. cit. supra note 28, at 387: "Die Völkerrechtsnormen haben also so viele Geltungsgründe als Staaten".

59. Verdross, supra note 35, at 252; Scott, L'Universalité du Droit des Gens (1927) I R. D. I. 637.

60. Verdross, supra note 35 , at 266.

6I. Id. at 269 ; Verdross, Grundlagen (supra note 22), at 80. This reason led Verdross to abandon his former construction. On state succession see the works of Huber and Feilchenfeld.

62. See supra note $I$.

63. JURISTische GrundLEHRE (1917) 155.

64. As "the norms of a habitually obeyed, omnicompetent, permanent highest might". Id. at I05. Such a might is termed "Rechtsmacht". It may be subject to a higher might (as the international might which produces international law) but not to a higher "Rechtsmacht"; for then the latter and not the former would be "Rechtsmacht". Id. at I6\%. The other three elements are also found missing in international law. Id. at I59, I62, I63.

"65. To be termed "international or super-state norms".

66. Op. cit. supra note 63 , at 170 .

67. TRIEPEI, op. cit. supra note 18 , at 32 . 
international law and the law of the land are distinct legal systems. ${ }^{68}$ This view is therefore called the dualistic construction.

Collective will in the sense here spoken of is not a mere aggregate of concurring wills, as in the jus gentium of Schoen, Wenzel and Verdross previously discussed. If the will of one state is insufficient to create international law, the sum of such wills is equally incapable of doing so. ${ }^{69}$ It is like the collective will of Rousseau, a volonté générale as distinguished from the volonté de tous. ${ }^{70}$

But how is this collective will formed? What makes it binding? Preexisting rules of law must be presupposed for that purpose. ${ }^{71}$ Triepel acknowledges that the validity of the ultimate norm in a legal system can not be explained juridically. He advances as an ethical justification for the binding force of the collective will the fact that each state finds in the collective will not only the will of others but its own will as well. ${ }^{72}$ In this fashion, the kinship of this theory with the social contract philosophy, a fact which has not escaped notice, ${ }^{73}$ is clearly shown. It is a form of natural law on the "constitutional" plane.

68. Id. at 9; see Pound, Common Law and Legislation (I908) 2I HARv. L. REv. 383, 395.

69. Mausbach, op. cit. supra note 32, at I04; Hetlborn, Grundbegriffe des VölkerRECHTS (1912) 36.

70. Contrat Social, II, iii; Anzilotti, Corso (Ist ed. 1912) 47. Yet Anzilotti says $(24,25)$ that the state can not be bound without the concurrence of its own will; nevertheless its own will alone is not sufficient to create international law. JELLINEK, op. cit. stipra note 42 , at 480 , says there are two alternatives. Either the will of each state remains separate in the mixture, and then one is back to the point where the auto-limitation theory begins, and must show how the state can bind itself; or else a new will emerges, and it becomes necessary to show a "bearer" for such will, in the shape of a super-state or civitas maxima. Impressed by the untenableness of the latter view, and considering the autolimitation theory a logical monstrosity, Strupp abandoned the collective will theory in favor of that resting the binding force of the declared will of states upon the fundamental norm pacta sunt servanda.

Krabbe, Kelsen and Verdross have pointed out that a rule of law is presupposed in order to ascertain what acts of human beings are to be considered as expressing the "will of the state". "Yet if one insists on defining law as the will of the state, there must be an international "state" before an international law can exist. If so, it seems clear that such a state differs from what are ordinarily called states in that its commands do not cover as comprehensive a sphere of conduct, but are confined to regulating international relations (HOLD-FERNECK, op. cit. sipra note 25, at 88; SOMLó, op. cit. supra note I8 at I59; FEILCHENFELd, op. cit. supra note II, at 582), and in that it would have no fellows. Sir J. F. Williams, Book Review (193I) 45 HARv. L. REv. 225, 227.

One might conclude that no international law is possible, for it would be either "äusseres Staatsrecht" of individual states on the one hand or "inneres Staatsrecht" of a super-state on the other. Yet we have seen (supra note 57) that the coexistence of independent states is one of the distinctive features of our problem. The autonomy of states constitutes the antinomy of international law. See Conclusion, infra. Cf. DEI VeCCEro, LEZIONI, supra note I8, at 273; ANZILOTTI, Corso (3d ed. I928) I, 45.

71. Verdross, supra note 35, at 277; AnzilotTI, CoRso (3d ed. 1928) 43; Williams, op. cit. sispra note $I$, at I7; Polrtis, The New Aspects of INTERnational Law (r928) 5 .

72. TrIEPEI, op. cit. supra note 18, at 82 . ANzILOTTI, Corso (Ist ed. IgI2) 27 regards the collective will as binding because it is in fact accepted as such by states.

73. Hudson, supra note 8, at 429; KOHLER, GRuNDLAGEN DES VölKERREchts (I918) 7 ; RADBRUCH, RECHTSPHILOSOPHIE (3d ed. 1932) I93; CAVAGLIERI, LA CONSUETUdiNE GIURIDICA (Ig07) 68, 7 I. 
We have now seen that to explain why international law is legally binding, it is necessary to refer to its fundamental legal norm, or constitution. What is the content of that basic norm?

Anzilotti declares that the fundamental norm of the international legal system is pacta sunt servanda. ${ }^{7 *}$ Verdross has shown that that principle is more than positive law for the practitioner; it appeals to the philosopher of law as well, because it is an expression of objective justice, having root in the realm of ethical values. ${ }^{75}$ The constitution includes the rule pacta sunt servanda, ${ }^{70}$ but may include others in addition. ${ }^{77}$ In fact that rule alone is not enough. ${ }^{78}$ Verdross recently formulated the content of the basic norm as a command that, subject to observance of more precise provisions established by treaty and custom, sovereign communities should govern their mutual conduct in accordance with "general principles of law". ${ }^{79}$

Postulation of the legal order is the important thing. Once the basic utterance fiat lex, whether induced by moral or material necessity, has given life to a juridical structure and indicated how its growth is to be governed, the jurist may pursue his task in confidence.

\section{The Nature of International Law}

Most of the matter that would appropriately fall under this heading has already emerged during the foregoing discussion of the binding force of international law; for it is by comparison of his notions regarding the nature of law with those regarding the nature of international law that

74. Conso (3d ed. I928) 43. (So too Strupp, op. cit. supra note 29, at 5 , who also formerly adhered to the collective will theory.) Hence any jus inter potestates whose rules derive their binding force from a fundamental norm pacta sunt servanda is part of international law. ANzILOTrI, CoRso (3d ed. I92S) II9, I29, I3I; VERDross, op. cit. supra note Io, at II6-II7.

75. Fondement (supra note 35), at 286; VerFassung (supra note 10), at 3I.

76. EINAEIT (silpra note 22), at 106 . The fundamental principle of good faith ("Treu und Glauben") for which Hold-Ferneck ( $O p$. cit. supra note 25, at 200 , 20I) contends is practically equivalent to pacta sunt servanda. It is perhaps preferable in that it does not suggest a limitation to treaty obligations, but would obviously include both of Le Fur's rules of natural law. Radbruch, in his RECrTSP HILOSOPHIE (3d ed. 1932) 82, regards as the fundamental norm of all positive law the precept enjoining obedience to the powers that be. RoMans, 13, I.

77. EINHEIT (supra note 22), at 59; Wriliams, op. cit. supra note I, at I7.

78. Grundlagen (supra note 22), at 84 Sir John Fischer Williams (1931) Treaty Revision and the Futture of the League of Nations, Io INT. AFF. 328, declares: "I do not accept the idea that the one and only fundamental doctrine of international law is pacta sunt servanda". Customary law must be included. Balladore-Pallieri, op. cit. supra note 37, at 342, 369. Besides the concept of the state in international law [cf. FEILCHENFELD, 602; ANzILotrI, CoRso (3d ed. 1928) I, 5I, II5], provision must be made for the modification of law and the imposition of obligations upon states not actually contracting. Grundlagen, 89. Bruns, supra note 20 , at $28-29$ is emphatic to the effect that pacta sunt servanda does not explain why states are bound against their will.

79. Verdross, Die allgemeinen Rechtsgrundsätze als Völkerrechtsquelle, in GEsELL-

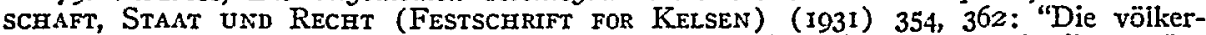
rechtliche Grundnorm würde also etwa folgenden Inhalt haben: Souveräne und teilsouveräne Rechtsgemeinschaften, verhaltet Euch in Eueren gegenseitigen Beziehungen nach den allgemeinen Rechtsgrundsätzen, soweit sich nicht im internationalen Verkehre besondere, von jenen Grundsätzen abweichende, gültige Normen herausgebildet haben". As to "general principles of law", see infra, "The Nature of International Law". 
every jurist must determine whether, in his judgment, the complex of norms known as international law possesses binding force as law. Only one or two minor points of interest remain to be mentioned here.

Modern legal science recognizes that law is made up of more than imperative, specific precepts. In addition to express enactments of legislative character and historically demonstrable customs, there is an ideal element embodying traditional conceptions of justice and modes of legal thought. ${ }^{80}$ Some writers on international law designate this element as "international equity law", or include it under the rubric of customary law. ${ }^{81}$ Following the language of the Statute of the Permanent Court of International Justice, Verdross and subsequent writers adopt the preferable usage of understanding by customary law only those rules which are based upon actual tacit consent of states, ${ }^{82}$ and utilizing the expression "general principles of law" s3 to denote that residual part of positive international law which does not originate from veritable consent of states. ${ }^{84}$

Another valuable contribution of Verdross in respect of the nature of international law is his exposition of the character of sovereignty. A distinction is drawn between two senses in which the term "sovereignty" may be used. Sovereignty in the sense of being the highest legal authority belongs only to the law, the fundamental norm. State sovereignty is independence of a superior, in the sense in which Bodin spoke of the sovereign, who, although bound by the laws of God and nature (hence by the international law of that epoch), had no suzerain over him. ${ }^{85}$

80. Dumbauld, Interim Measures of Protection in International Controverstes (I932) $\$ 76$, and authorities there cited. See also Pound, Book Review (I933) 46 HARv. L. REv. 864, 868.

8r. Id. at I75.

82. VERDRoss, Verfassung (supra note I0) 57. Agreement implied in fact, rather than implied in law, to use common law terminology. A view prevalent since Grotius (VERFASSUNG 54) regards custom as a "tacit pact", hence as an expression of common consent of states just as much as an express treaty. Cf. CavaGLIERI, op. cit. supra note 73, at 72. But much of what is called customary law really does not involve actual, conscious consent, an act of will. Balladore-Pallieri, supra note 37, at 342; GIANNI, LA COUTUME EN DroIT INTERNATIONAL (I93I) II9, 159. With the realization that the binding force of international law does not rest upon the consent of states, but upon the basic norm, the fiction of tacit consent may be abandoned. Verdross, supra note 79 , at 359 . The fundamental norm clothes "general principles of law" with binding force directly, just as it recognizes treaty and custom as sources of law. Id. at 362 . According to BalladorePallieri, I "Principi Generali del Diritto Riconosciuti dalle Nazoni Civili" nell" Art, 38 DErLo Statuto deila Corte permanente di GiUstizia internazionale (I93I) 64, resort to "general principles of law" is sanctioned by a rule of customary law. Cf. Verdross, VERFASSUNG 59.

83. The principles of law in question must reflect a substantially unanimous conviction with respect to weighty presuppositions of civilized international life. Härle, Die allgemenen Rechtsgrundsätze im Völkerrecht (Deutschland, I93I) II ZT. F. ÖFF. RT. 234; BALIADOREFallierI, Pritcipi, supra note 82 , at 73 ; Verdross, supra note 79 , at 364 . For examples of such principles see Duarbauld, op. cit. supra 178 , and Verdross, Die Quellen des Völkerrechts (Deutschland, I930) Io MitTEILUNGEN DER DEUTSCHEN GESELLSCHAFT FÜR VöLKERRECHT 8I, 89.

84. ANzILotTr, Corso ( $3 \mathrm{~d}$ ed. I928) I, 64, still regards custom as a tacit pact [Cf. CoRso (Ist ed. IgI2) I, 52]. But is not that opinion a case of the false positivism criticised in CoRso (3rd ed. 1928) I, I13? See also notes 103 and 108 infra.

85. VERDRoss, DIE EINHEIT DES RECHTLICHEN WeLtBILDES (1923) I. Abschnitt. 
A state's sovereignty is thus a legal sphere of action conferred by international law. States are endowed with constitutional autonomy, and possess sovereignty by reason of their direct dependence from international law, without the intervention of any intermediate legal order. ${ }^{86}$ As organs of international law, charged with the task of executing its provisions, they are assigned certain provinces of exclusive jurisdiction, as well as certain definite obligations. ${ }^{87}$ Other spheres (such as jurisdiction over the high seas) are entrusted to all states equally, ${ }^{88}$ or to groups of states, ${ }^{89}$ or directly to international organs, such as the Saar commission. ${ }^{90}$

\section{The End of Law}

According to Dean Pound, ${ }^{91}$ a study of legal history reveals various conceptions of the end of law in different epochs. (x) In primitive law, the paramount purpose was to preserve peace by appeasing the wronged party's desire for vengeance. This was accomplished by a tariff of compositions, which the state as time went on compelled the wrongdoer to pay and the victim to accept. The amount of compensation did not depend so much on the gravity of the offense, measured by an objective standard, as upon the intensity of resentment aroused and the degree of violence to which it was likely to lead. (2) In the period of strict law, the object was to maintain the social status quo. Rigid formalism characterized the requirements for setting in motion legal remedies and rights of action. Form rather than substance was stressed. (3) An infusion of ethical elements entered the law during the era of equity and natural law. This epoch was marked by an excessive, because ineffectual, desire to accomplish ethical ends and achieve true justice. Emphasis was upon duties rather than rights. (4) Then came the maturity of law, strictly separating law from morals and laying weight upon abstract legal rights, especially property and contract, with a view to assuring the maximum of individual selfassertion under a general law of freedom. Security of acquisitions and security of transactions were watchwords of this period. (5) Enfin vint Malherbe. Recent years have seen the growth of a conception of jurisprudence as social engineering seeking to reconcile conflicting claims so far as possible and to protect interests rather than rights as such. Social justice rather than legal justice is sought. ${ }^{92}$

A survey of international law will reveal that all of these elements may be found present at the same time side by side. Diplomatic protection

86. Verdross, op. cit. supra note Io, at II5.

87. Id. at $75-76$.

88. Id. at 45 .

89. Id. at 2 II et seq.

90. Id. at 77 et seq.

91. The End of Law as Developed in Legal Rules and Doctrines (IgI4) 27 Harv. L. REv. I95, Ig8 et seq.

92. Social Justice and Legal Justice (1912) 75 CENT. L. J. 455. 
of nationals abroad and state responsibility for injury to foreigners exhibit a survival of the solidarity between members of the same tribe or clan which characterized primitive law. The redress afforded is similar to wergild. And it is not unthinkable that a weak state, to appease the wrath of a powerful neighbor, may make ampler retribution than would be the case if the situation of the parties were reversed. ${ }^{93}$

So too international law presents the spectacle of strict insistence on the letter of engagements and rigid formalism with respect to rights of action. Resort to international tribunals is not accepted as the normal method of settling controversies, and narrow legalistic objections to jurisdiction are raised. ${ }^{94}$ States espousing the claims of their nationals in order that proceedings may be instituted in international courts remind one of the familiar John Doe in actions of ejectment. ${ }^{95}$ An opinion is also noticeable which attaches great weight to preservation of the territorial, economic and political status quo established at the end of the world war. ${ }^{96}$

As we have seen already, natural law doctrines are again springing up. The rights of man and married women enjoy particular favor in present day discussion. ${ }^{87}$

Self-assertion and clinging to abstract legal rights can find no better illustration than that afforded by the dominant doctrine of state sovereignty in international law. ${ }^{98}$ Yet a growing mass of social and humanitarian legislation in the international field shows that the world is awake to the necessity of protecting social iriterests by means of legal machinery. Sociological jurists are calling for immediate application of their methods to the problems of international law.99 Here too "the time has gone by when law is only an unconscious embodiment of the general will. It has become a conscious reaction upon itself of organized society seeking to determine its own destinies." 100

The coexistence of these various elements gives reason to hope that international law may be spared the necessity of successively passing through every stage of development through which private law has passed

93. Borchard, Theoretical Aspects of the International Responsibility of States (Deutschland, I929) I ZEITSChrift F. AUS. öFF. RT. U. VöLKERRECHT, I Teil, $247,249$.

94. Bruns, supra note 20 , at 35.

95. Case concerning Serbian loans, Publications of the Permanent Court of International Justice, series A, no. 20/2I (1929).

96. This delusion is no new one. "Imperial Rome, unlike sacred Troy, was to be eternal; the Holy Roman Empire was to be the heir of that eternity. The Treaties of Westphalia, of Utrecht, of Vienna, of Berlin, none of them so far as I know, made provision for change or included any clause of revision. And nevertheless the pontifex and the silent virgin no longer climb the Capitol, and the Holy Alliance is as impotent as the royal tenants of the Abbey of St. Denis." Williams, supra note 78 , at 327 .

97. See Scott, Le Progrès du Droit des GENS (1930).

98. See Brierly, The Shortcomings of International Law (1924) Britise Yearboox OF INTERNATTONAL LAW 4, 12 .

99. Pound, sippra note 3 , at 89 ; Hudison, supra note 8 , at 435 .

IOO. Holmes, Collected Legal Papers (I921) I29, I30. 
in the course of history. ${ }^{101}$ Every advance in jurisprudence must be promptly turned to account in the development of international law.

\section{Conclusion}

Philosophy should play in international law much the same rôle as in other legal systems. Its chief concern is with the problems which are at the bottom of the legal structure. It tells us what law is, and what it is for. ${ }^{102}$ Yet philosophy is not without its part in developing specific rules of law, as it liberates juristic processes from bondage to fixed ideas and cramping concepts. By undermining ancient error and distinguishing substance from shadow it exorcises many a fearsome phantom. ${ }^{103}$

With respect to the foundations of international law, we have seen that the problem consists in reconciling as neatly as possible the following propositions: (I) Law is a binding norm laid down by a superior authority; (2) A state can not be bound except by its own will; (3) International law is not the product of the will of any single state; (4) International law is law, binding every state.

Legal antinomies are not unlike the other antinomies of philosophy. That a person can not obligate himself; that nothing outside himself can obligate him; and that obligation exists presents a situation resembling the philosophical problem of epistemology: the knower and known are separate and transcendant, yet knowledge of the object by the subject is a phenomenon whose existence is clear. ${ }^{10 t}$ Philosophy should teach the lawyer to avoid making practical problems out of intellectual difficulties, but instead to utilize theoretical achievements for the clarification of practice; for practice is the theory of those who are in positions of authority.

To summarize the results of our survey:

(I) International law is international; it is not the internal law of a super-state or of a multitude of states, a composite structure like "criminal law" or "contracts", a conglomeration of rules prevailing in many jurisdictions with respect to a common subject-matter. It is a universal unity,

IoI. Thus Professor Hudson voices the hope that international government may be saved from certain dogmas which have been dominant in political theory. Book Review (I93I) 44 HARV. L. REV. I3II.

102. It is important to avoid the reproach of Bacon: "Philosophers make imaginary laws for imaginary commonwealths, and their discourses are as the stars, which give little light because they are so high". "Quoted in HigGris, StLifs In InTERNational Law AND RELATIONS (1928) 5.

103. Thus Niemeyer, in Einstweilige VhrFi"gligex des WeltGerichtshofs, IHR WESEN UND IHRE GRENZEN (I932) occasionally understates the positive law as to judicial remedies pendente lite because of a philosophical conviction that there are immanent or inherent limitations on international jurisdiction arising out of the nature of international law. The truth is that states may agree to settle any dispute by any method. Sir Jolnn Tischer Williams, Justiciable and Other Disputes (1932) 26 AM. J. INT. L. 31, 34; ScotT, Sovereign States and SUITs (1925) 147. The question of justiciability therefore must always be determined by scrutiny of positive law.

IO4. A good treatment of the problen of knowledge is contained in Nicolai HARTMANN, GRundzüge eINER METAPHYSIK DER ERKENNTNis (2d cd. Ig25). 
having its own constitution and community, made up of independent states.

(2) That the fundamental norm is binding must be shown upon moral or political extra-legal grounds. ${ }^{105}$ Here may be considered the facts of international intercourse, the pressure of commercial needs and humanitarian desires. ${ }^{106}$

(3) What the content of the fundamental norm is must be ascertained by observation. It includes the rule pacta sunt servanda. ${ }^{107}$

(4) The fundamental norm prescribes how law is to be made. Sources so referred to are convention, custom and general principles of law. ${ }^{108}$

(5) International law sets the orbit within which states may exercise their jurisdiction. ${ }^{109}$ The doctrine that the jurisdiction of states is not unlimited, embracing the whole world, but has definite boundaries is one of the chief contributions of Anglo-American legal thought to the science of international law. ${ }^{110}$

(6) International law is not the source of state law and power, but a limitation on it; just as states in the American union derive authority from their own constitutions but are curbed by the federal Constitution. ${ }^{111}$ If the monistic construction bringing international law and the internal law of every state within the same legal system is to be preserved, it must be on the basis of common dependence upon a higher norm. ${ }^{112}$

105. Anzilotrt, CoRso (3rd ed. I928) 42; Verdross, supra note 19, at 355; TRIEPEL, op. cit. supra note 18 , at 82 .

I06. NeLson, op. cit. supra note 34, at 95 ; Le Fur, Le Droit Naturel au Objectif, s'étendil aux Rapports Internationant? (Belgique I925) 52 R. D. I. L. C. 59, 61; JerlinEK, Rechtulche NATUR (I880) 48, 49; Schoen, silpra note 28, at 303; FAUCHILle, op. cit. supra note 57 ; Perassi, supra note 20 , at 214 , 222; STRUPp, GRUNDzÜGE (I928) I.

I07. That rule exists also as a norm of ethics, and as such is an element under (2) to show why international law is a social necessity. Sonró, op. cit. supra note 18, at 172; Perassi, supra note 20 , at 212 .

I08. Therefore one must scrutinize the sources rather than look for actual consent by particular states. To indulge in speculations about "sovereignty" when seeking to ascertain the existence and extent of a rule of international law is as out of place as similar discussion of "freedom" and the "rights of man" in a suit for collection of a debt. Bruns, stipra note 20 , at 33, 35. States become bound by international law "not by any act of their own, express or implied" but "just in the same way as an individual is bound by municipal lawthat is to say, as an inevitable result of birth into a society ruled by that law": WrLliars, op. cit. supra note $\mathrm{I}$, at I4. Once the existence of an international legal order is established, whether by consent of states or the exigencies of nature or any other way, nothing but the "constitutional" rules of the legal system may be looked to for the purpose of ascertaining the content of the law in force in the community.

I09. Cf. KELSEN, op. cit. supra note 23 , at I2I.

ro. Leo Gross, Der Rechtsbeyriff des Common Law antd das Völkerrecht (Deutschland, 193I) II ZEITSCHRIFT FÜR ÖFFENTLICHES RECHT 366.

iII. ANzilottr, Corso (3rd ed. I928) 49.

II2. VERDROSS, DIE vöLKERRECHTSWIDRIDGE KRIEgSHANDLUNG UND RER STRAFANSPRUCH DER STAATEN (I920) 4I, n. 75, mentions this possibility but regards it as of no practical importance. Cf. KELSEN, op. cit. supra note 23, at 199, 200, for analogous treatment of the relation between federal and local law. 